\title{
Scanning electron microscopy of the oral apparatus and buccopharyngeal cavity of Atelognathus salai larvae (Anura, Neobatrachia)
}

\author{
Dinorah D. Echeverría ${ }^{1}$, Carmen A. Úbeda², and Néstor G. Basso ${ }^{3}$ \\ 1 Facultad de Ciencias Exactas y Naturales, Universidad de Buenos Aires. Departamento de Biodiversidad y Biología \\ Experimental, Laboratorio de Vertebrados, 1428 Buenos Aires, Argentina. E-mail: echeverria@bg.fcen.uba.ar. \\ 2 Centro Regional Bariloche, Universidad Nacional del Comahue, Unidad Postal Universidad, R 8400 FRF Río Negro, \\ Argentina. E-mail: cubeda@bariloche.com.ar. \\ ${ }^{3}$ Centro Nacional Patagónico, Blvd. Brown 3500, 9120 Puerto Madryn, Chubut, Argentina. E-mail: nbasso@cenpat.edu.ar.
}

Keywords: Anura, Neobatrachia, Atelognathus salai, tadpole, oral apparatus, buccopharyngeal cavity, morphology.

Frogs of the genus Atelognathus form a clade of nine narrowly distributed species restricted to Patagonia, southern Argentina and Chile, characterized by a large, exposed frontoparietal fontanelle, short palatines, large nasals and by the absence of quadratojugals and middle ear elements. Although Frost et al. (2006) have included Atelognathus in the redefined family Ceratophryidae, we have data to support a new alternative arrangement (Basso, Hillis and Cannatella in prep.). Atelognathus salai Cei, 1984 is known only from its type locality: Laguna de los Gendarmes and nearby ponds, north of Lake Buenos Aires, Santa Cruz Province, Argentina.

Of the nine Atelognathus species known today (Basso 1998, Meriggio et al. 2004), only the tadpoles of A. patagonicus (Cei 1965), A. reverberii (Cei 1969), A. nitoi (Basso and Úbeda 1997), A. salai (Úbeda and Basso 2003), and A. jeinimenensis (Meriggio et al. 2004)

Received 18 July 2005.

Accepted 7 December 2005.

Distributed September 2006. have been described. Wassersug and Heyer (1988) described the microanatomy of the buccopharyngeal cavity of Atelognathus reverberii and A. patagonicus. Echeverría et al. (2001a) summarized the general features of the oral morphology of the genus Atelognathus in their description of the fine surface structure of the buccopharyngeal cavity of Atelognathus nitoi.

The aim of this study is to describe the horny structures of the buccal apparatus and buccopharyngeal cavity of $A$. salai by means of scanning electron microscopy (SEM), and to compare them to those of the other known species of Atelognathus and related genera.

The morphological descriptions are based on two tadpoles of $A$. salai collected from the type locality, Laguna de los Gendarmes (46 $06^{\circ}$ 'S, $\left.71^{\circ} 41^{\prime} \mathrm{W}\right)$, Santa Cruz Province, Argentina. The specimens, at stages 37 and 38 of Gosner's normal development table (Gosner 1960), are deposited at the collection of the Facultad de Ciencias Exactas y Naturales, Universidad de Buenos Aires, Argentina (LARV-DDE-FCEN228-229). 
The specimens were treated according to the techniques for scanning electron microscopy (SEM) described by Wassersug (1980) and Echeverría (1995), which included a rapid dehydration in ethyl alcohol (80\%, 8 h; 96\%, 2 h; $100 \%, 1$ h), ethyl alcohol-acetone (3:1, 1 h; $1: 1,1 \mathrm{~h} ; 1: 3,1 \mathrm{~h}$ ) and pure acetone not more than two hours before the final dehydration. Critical-point dehydration was done in a Balzers ${ }^{\circledR} 030$ vacuum dryer. Specimens were coated in gold using an ION Balzers ${ }^{\circledR}$ CPD 040 sputter coater. A Philips ${ }^{\circledR} 505$ scanning electron microscope was used for observations and photographs. Terminology in the descriptions of the horny structures of the buccal apparatus and buccopharyngeal cavity follows Deunff and Beaumont (1959), Viertel (1982) and McDiarmid and Altig (1999). The dental formula terminology is based on Altig (1970).

The labial teeth form continuous, homogeneous rows (labial tooth row formula: 2(2)/ $3(1))$. The number of teeth in a row at stage 37 is approximately 5 to 7 per $100 \mu \mathrm{m}$. Each tooth comprises a base, a neck, and a paddle with 14 to 16 short, subequal marginal serrations (denticles). The total length of a labial tooth is 25-30 $\mu \mathrm{m}$, with maximum paddle width of 15 $\mu \mathrm{m}$ (Figure 1A). The jaw sheath teeth are arranged in a palisade, with a density of 4-5 teeth per $100 \mu \mathrm{m}$; the total tooth length is approximately 30-35 $\mu \mathrm{m}$ and the maximum width is $20 \mu \mathrm{m}$ (Figure 1B).

On the buccopharyngeal cavity floor, the prelingual region has six infralabial papillae: two ventral and four lateral (Figure 1C). Four simple lingual papillae are present on the lingual anlage; the central papillae are longer and closer to the anterior lingual margin (Figure 1C). The buccal floor arena is limited laterally and posteriorly by peripheral papillae (Figure 1D). The buccal pockets are elongated, located transversally to the medial line. The internal lateral area of the prepocket is preceded by laminar projections, with two tall, well developed, digitiform tips pointing towards the interior of the buccopharyngeal cavity. Near the anterior edge of the pocket, there are 2 to 3 low papillae oriented towards the buccal pocket (Figure 1D). The ventral velum has four pronounced, widely separated marginal projections on each side of the medial notch. There are glandular pits on the velum margin and its projections.

On the buccopharyngeal cavity roof, there are elliptical choanae oriented transversally to the cephalocaudal axis. In the postnarial area, there are two pairs of postnarial papillae of different sizes, the medial pair being the most developed (Figure 1E). The lateral ridges are triangular-shaped projections, compressed anteroposteriorly, and with irregular edges. The median ridge is triangular, with smooth walls and irregular edges. The buccal roof arena is delimited by 6 pairs of tall, conical marginal papillae, and numerous pustules. The glandular area is well developed, arranged in an open Ushaped band. The secretory pits are circular or irregular shaped (Figure 1F).

Figure 2 shows the buccopharyngeal cavity features for A. salai at stage 37. There is a large morphological and morphometric similarity between the labial teeth of $A$. salai and $A$. nitoi (Echeverría et al. 2001a), although A. salai has more denticles per paddle. Some of the anatomical features of the buccopharyngeal cavity of $A$. salai are common to other leptodactylid tadpoles. The four lingual papillae present in A. salai are also present in the other known species in the genus Atelognathus and in the tadpoles of the leptodactylid genera Alsodes, Batrachyla, Caudiverbera, Hylorina, Pleurodema and Odontophrynus (Brieva Vásquez 1988, Wassersug and Heyer 1988, Echeverría et al. 2001a,b).

The morphology of the buccopharyngeal cavity of the tadpoles of $A$. salai resembles most A. patagonicus, A. reverberii (Wassersug and Heyer 1988) and A. nitoi tadpoles (Echeverría et al. 2001a) in having four lingual papillae; four of the six infralabial papillae enlarged; a triangular median ridge; and simple, welldeveloped lateral ridges. 

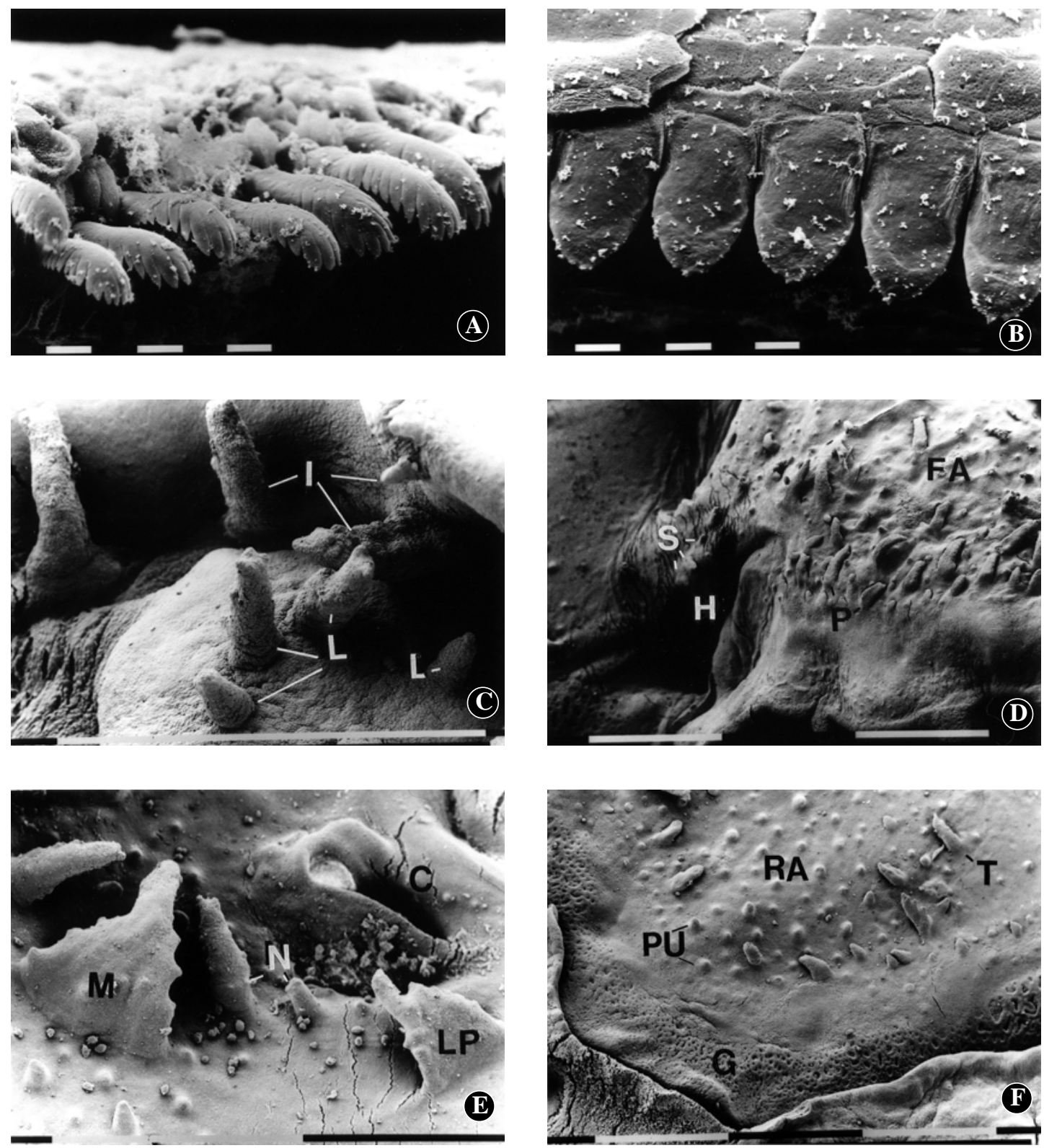

Figure 1 - Oral morphology of tadpoles of Atelognathus salai (stage 37). (A) Labial teeth of A-2 row of the oral disc; (B) Teeth of the upper jaw sheath of the oral disc; (C) Anterior region of the buccopharyngeal cavity floor; (D) Median and posterior region of the buccopharyngeal cavity floor; (E) Buccopharyngeal cavity roof, anterior region; (F) Buccopharyngeal cavity roof arena and posterior glandular region. Symbols: C, choana; FA, buccal floor arena; G, glandular region; H, right buccal pocket; I, infralabial papillae; L, lingual papillae; LP, lateral ridge; $\mathrm{M}$, median ridge; N, postnasal papilla; P, peripheral papillae; PU, pustules; RA, buccal roof arena; S, papillae of the anterior margin of buccal pocket; $\mathrm{T}$, papillae of the arena margin. Scale lines $=10$ $\mu \mathrm{m}(\mathrm{A}-\mathrm{B})$ and $1 \mathrm{~mm}(\mathrm{C}-\mathrm{F})$. 

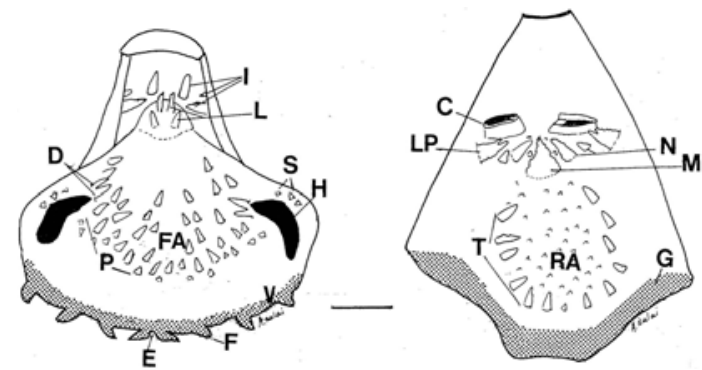

Figure 2 - General morphology of the buccopharyngeal cavity of the tadpole of Atelognathus salai (stage 37). Left: floor, right: roof. Symbols: C, choana; D, prepocket papillae; E, median notch; F, marginal projection; FA, buccal floor arena; G, glandular region; $\mathrm{H}$ buccal pocket; I, infralabial papillae; L, lingual papillae; LP, lateral ridge; $\mathrm{M}$, median ridge; $\mathrm{N}$, postnarial papillae; P, peripheral papillae of the buccopharyngeal cavity floor area; RA, buccal roof arena; S, papillae of the anterior margin of $\mathrm{H}$; $\mathrm{T}$, papillae of the margin of the buccopharyngeal cavity roof arena; V, velum. Scale line = $1 \mathrm{~mm}$.

The dental formula of A. salai [2(2)/3(1), Úbeda and Basso 2003] is generalized and widespread among different types of tadpoles, and cannot be related to a particular aquatic environment. It is present in Patagonian leptodactylid frogs inhabiting temporary or permanent, lotic or lentic environments with a variety of ecomorphological characteristics (i.e. Pleurodema thaul, P. bufonina, Hylorina sylvatica, Atelognathus spp., Alsodes spp., Batrachyla spp., Caudiverbera caudiverbera, and Odontophrynus occidentalis).

The morphology of the oral apparatus and buccopharyngeal cavity observed in A. salai matches the general descriptions for other Atelognathus species. The characteristics in common with other Patagonian leptodactylid frogs of different habits may be attributed mainly to phylogenetic constraint rather than to convergent ecological adaptations.

\section{Acknowledgments}

We are grateful to D. Jiménez, from the Scanning Electron Microscopy Service at the Instituto de Investigaciones Científicas y Técnicas de las Fuerzas Armadas (CITEFA). We also thank Ron Heyer and two anonymous reviewers for their critical comments on the manuscript. This study was funded in part by a research grant from the Agencia Nacional de Promoción Científica y Tecnológica (ANPCyT) of Argentina (PICT 01-03698) and a research grant from the Universidad Nacional del Comahue (B 101).

\section{References}

Altig, R. 1970. A key to the tadpoles of the continental United States and Canada. Herpetologica 26: 180207.

Basso, N. G. 1998. A new telmatobiine leptodactylid frog of the genus Atelognathus from Patagonia. Herpetologica 54: 44-52.

Basso, N. G. and C. A. Úbeda. 1997. The tadpole of Atelognathus nitoi (Leptodactylidae, Telmatobiinae). Alytes 15: 121-126.

Brieva Vásquez, L. M. 1988. Análisis morfológico comparativo de las larvas de las especies del género Batrachyla (Anura: Leptodactylidae). Unpublished Master's Thesis. Univ. Austral de Chile, Valdivia, Chile. 166pp.

Cei, J. M. 1965. The tadpole of Batrachophrynus patagonicus Gallardo. Herpetologica 20: 242-245.

Cei, J. M. 1969. The Patagonian Telmatobiid fauna of the volcanic Somuncura plateau of Argentina. Journal of Herpetology 3: 1-18.

Cei, J. M. 1984. A new leptodactylid frog, genus Atelognathus, from Southern Patagonia, Argentina. Herpetologica 40 : 47-51.

Deunff, J. and A. Beaumont. 1959. Histogénèse des dents et du bec cornés chez les larves de Discoglossus pictus Otth. Compte rendus Societé de Biologie 153: 11621164.

Echeverría, D. D. 1995. Microscopía electrónica de barrido del aparato bucal y de la cavidad oral de la larva de Leptodactylus ocellatus (Linnaeus, 1758) (Anura, Leptodactylidae). Alytes 12: 159-168. 
Echeverría, D. D., C. A. Úbeda and N. G. Basso. 2001a. Microscopía electrónica de barrido del aparato bucal y cavidad bucofaríngea de la larva de Atelognathus nitoi (Anura, Leptodactylidae). Alytes 19: 173-182.

Echeverría, D. D., C. A. Alonso, M. S. Pillado and C. A. Úbeda. 2001b. Microanatomía del aparato bucal y cavidad bucofaríngea de la larva de Alsodes gargola Gallardo, 1970 (Leptodactylidae,Telmatobiinae). Alytes 18: 187-200.

Frost, D. R., T. Grant, J. Faivovich, R. H. Bain, A. Haas, C. F. B. Haddad, R. O. de Sá, A. Channing, M. Wilkinson, S. C. Donnellan, C. J. Raxworthy, J. A. Campbell, B. L. Blotto, P. Moler, R. C. Drewes, R. A. Nussbaum, J. D. Lynch, D. M. Green and W. C. Wheeler. 2006. The amphibian tree of life. Bulletin of the American Museum of Natural History 297: 1-370.

Gosner, K. L. 1960. A simplified table for staging anuran embryos and larvae with notes on identification. Herpetologica 16: 183-190.

McDiarmid, R. W. and R. Altig (eds). 1999. Tadpoles - the biology of anuran larvae. Chicago and London, The University of Chicago Press. 633 pp.

Meriggio, V., A. Veloso, S. Young, and H. Núñez. 2004. Atelognathus jeinimenensis n.sp. de Leptodactylidae para el sur de Chile. Boletín del Museo Nacional de Historia Natural, Chile 53: 99-123.

Úbeda, C.A and N. G. Basso. 2003. The tadpole of Atelognathus salai Cei, 1984 (Leptodactylidae: Telmatobiinae). Amphibia-Reptilia 24: 112-118.

Viertel, B. 1982. The oral cavities of central European anuran larvae (Amphibia). Morphology, ontogenesis and generic diagnosis. Amphibia-Reptilia 4: 327-360.

Wassersug, R. 1980. Internal oral features of larvae from eight anuran families: functional, systematics, evolutionary and ecological considerations. Miscellaneous Publications of the University of Kansas Museum of Natural History 68: 1-146.

Wassersug, R. J. and W. R. Heyer. 1988. A survey of internal oral features of leptodactyloid larvae (Amphibia: Anura). Smithsonian Contributions to Zoology 457: 1-99. 